\title{
Computed Discharges at Five Sites in Lower Laguna Madre Near Port Isabel, Texas, June 1997
}

The Texas Water Development Board (TWDB), Texas Parks and Wildlife Department (TPWD), and Texas Natural Resource Conservation Commission (TNRCC) are charged by the Texas Legislature with determining freshwater inflows required to maintain the ecological health of streams, bays, and estuaries in Texas. To determine required inflows, the three agencies collect data and conduct studies on the needs for freshwater inflows to estuaries. The TWDB uses estuarine hydrodynamic and conservativetransport computer models to predict the effects of altering freshwater inflows on estuarine circulation and salinity. To calibrate these models, a variety of water-quality and discharge data are needed.

The U.S. Geological Survey (USGS), in cooperation with the TWDB, conducted an intensive hydrographic survey during June 19-22, 1997, to provide calibration data for a TWDB model of lower Laguna Madre near Port Isabel, Tex. The TPWD, U.S. Army Corps of Engineers Waterways Experiment Station, and Texas A\&M University-Corpus Christi Conrad Blucher Institute also participated in the study. Lower Laguna Madre is a shallow estuary between Padre Island, a barrier island along the southernmost Texas Gulf Coast, and the Texas mainland (fig. 1). Automated instrumentation and acoustic discharge-measuring technology were used to maximize the amount and quality of data that were collected and to minimize personnel requirements.

This fact sheet describes the hydrographic survey and the methods of discharge measurement and analysis and presents discharges computed for five sites to account for flow into, within, and out of the southern end of lower Laguna Madre during the approximately 74-hour survey period (three tidal cycles) of June $19-22,1997$.

\section{Lower Laguna Madre}

Lower Laguna Madre encompasses about 270 square miles (Hedgpeth, 1967, p. 409) and extends northward about 50 miles from Port Isabel, Tex. (fig. 1). The upper and lower bodies of Laguna Madre are connected by the Land Cut, a 26-mile reach of the Gulf Intracoastal Waterway (GIW) that breaches a broad area of sand dunes that, prior to dredging of the GIW, physically separated the two bodies of water. The average depth in Laguna Madre is less than 4 feet except in the GIW, in areas of the Arroyo Colorado, and in the main channels connecting Laguna Madre to

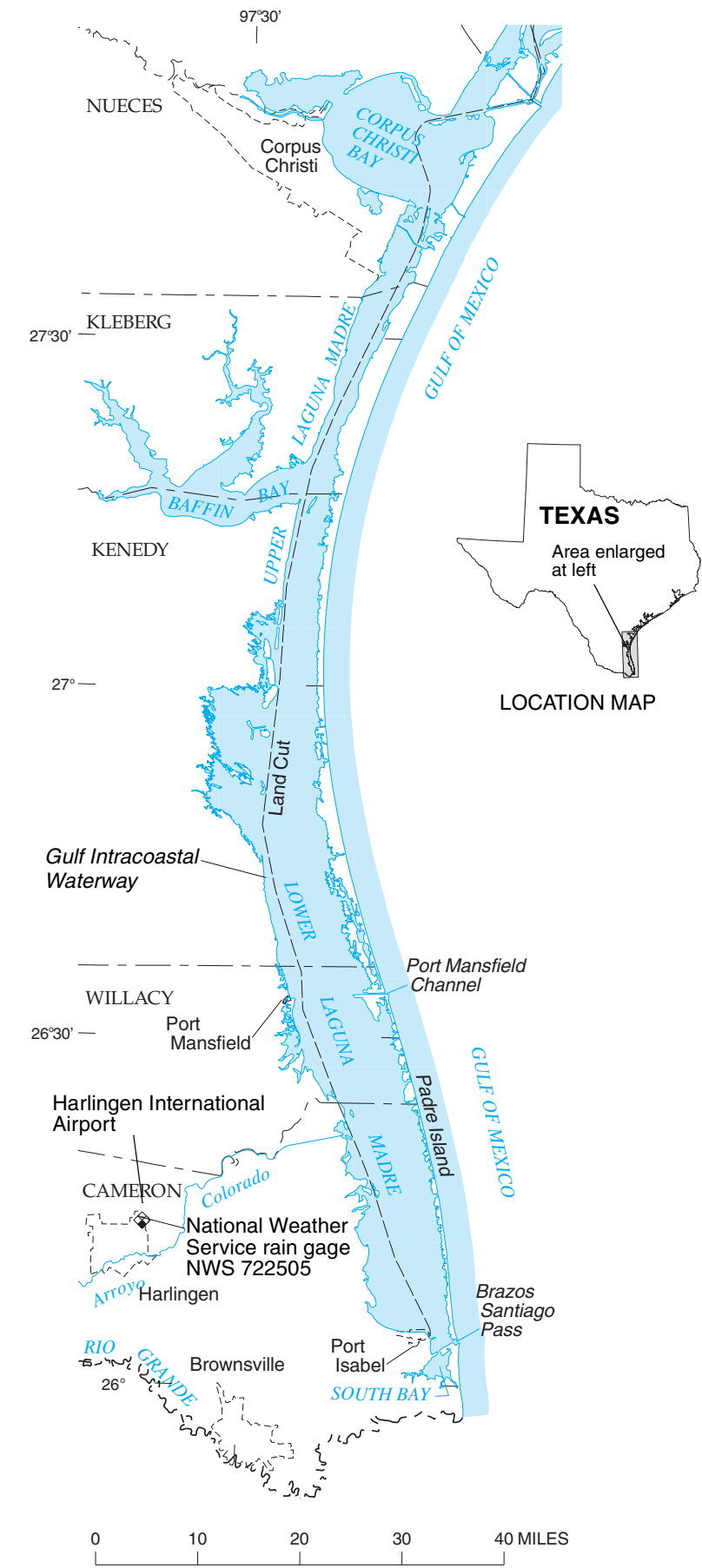

Figure 1. Southern Gulf Coast of Texas. 


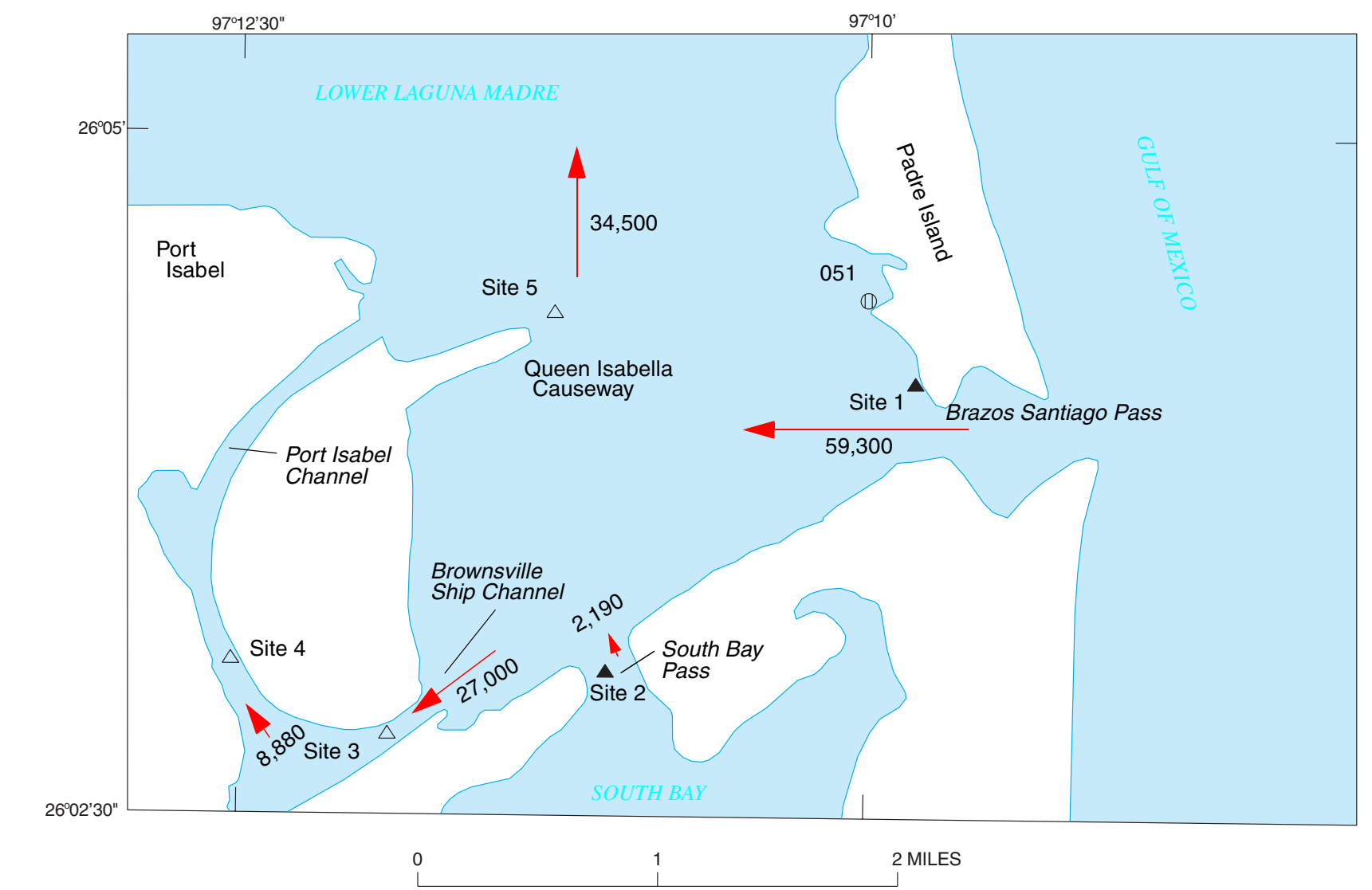

EXPLANATION

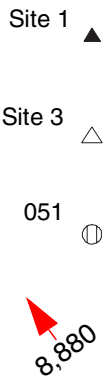

- Measurement site for velocity, stage, and dischargeSite number corresponds to site number in tables Measurement site for velocity and discharge-Site
number corresponds to site number in tables

(1) Texas Coastal Ocean Observation Network (TCOON) station

Net discharge volume in acre-feet and flow direction during 74-hour survey-Scale 1 inch = 50,000 acre-feet

Agency responsible for data collected at sites 1-5

\begin{tabular}{cccc}
\hline Site no. & Velocity & Stage & Discharge \\
\hline 1 & USGS & USGS & USGS \\
2 & TWDB & TWDB & TWDB \\
3 & USGS & -- & TWDB \\
4 & USGS & -- & TWDB \\
5 & USGS & -- & USGS \\
\hline
\end{tabular}

Figure 2. Measurement sites, net discharge volumes, and flow directions in lower Laguna Madre near Port Isabel, Texas, June 19-22, 1997.

the Gulf of Mexico-Brazos Santiago Pass and Port Mansfield Channel (Texas Department of Water Resources, 1983, p. III-1).

Freshwater inflows to lower Laguna Madre average less than 530,000 acre-feet per year (Texas Department of Water Resources, 1983, p. IV-2) and are concentrated primarily at Brownsville Ship Channel (fig. 2) and Arroyo Colorado (fig. 1). Because evaporation exceeds the sum of freshwater inflows to and precipitation on lower Laguna Madre, salinities in some areas at times exceed that of seawater (about 35,000 milligrams per liter dissolved solids) (Texas Department of Water Resources, 1983, p. V-11). Net flow in lower Laguna Madre generally is assumed to be in the direction of prevailing winds, which during the summer months predominantly is toward the northwest. During the summer months, Gulf waters are presumed to enter from the south at Brazos Santiago Pass, flow northward, and exit at Port Mansfield Channel or the Land Cut (Hedgpeth, 1967, p. 410), though little physical data exist to confirm the frequency or duration of this pattern. The flow pattern presumably reverses under the influence of winds from the north during winter months.

\section{Data-Collection Sites}

Rainfall data from the National Weather Service (NWS) rain gage at Harlingen International Airport (fig. 1) for the approximately 74-hour period of the hydrographic survey of lower Laguna Madre were obtained from the NWS. Wind velocity and direction and tide data were collected at a Texas Coastal Ocean Observation Network (TCOON) station (fig. 2), one of a series of observation stations along the southern Texas Gulf Coast maintained in part by the Texas A\&M University-Corpus Christi Conrad Blucher Institute.

The USGS and the TWDB collected velocity, stage, and discharge data at two sites-Laguna Madre at Brazos Santiago Pass 

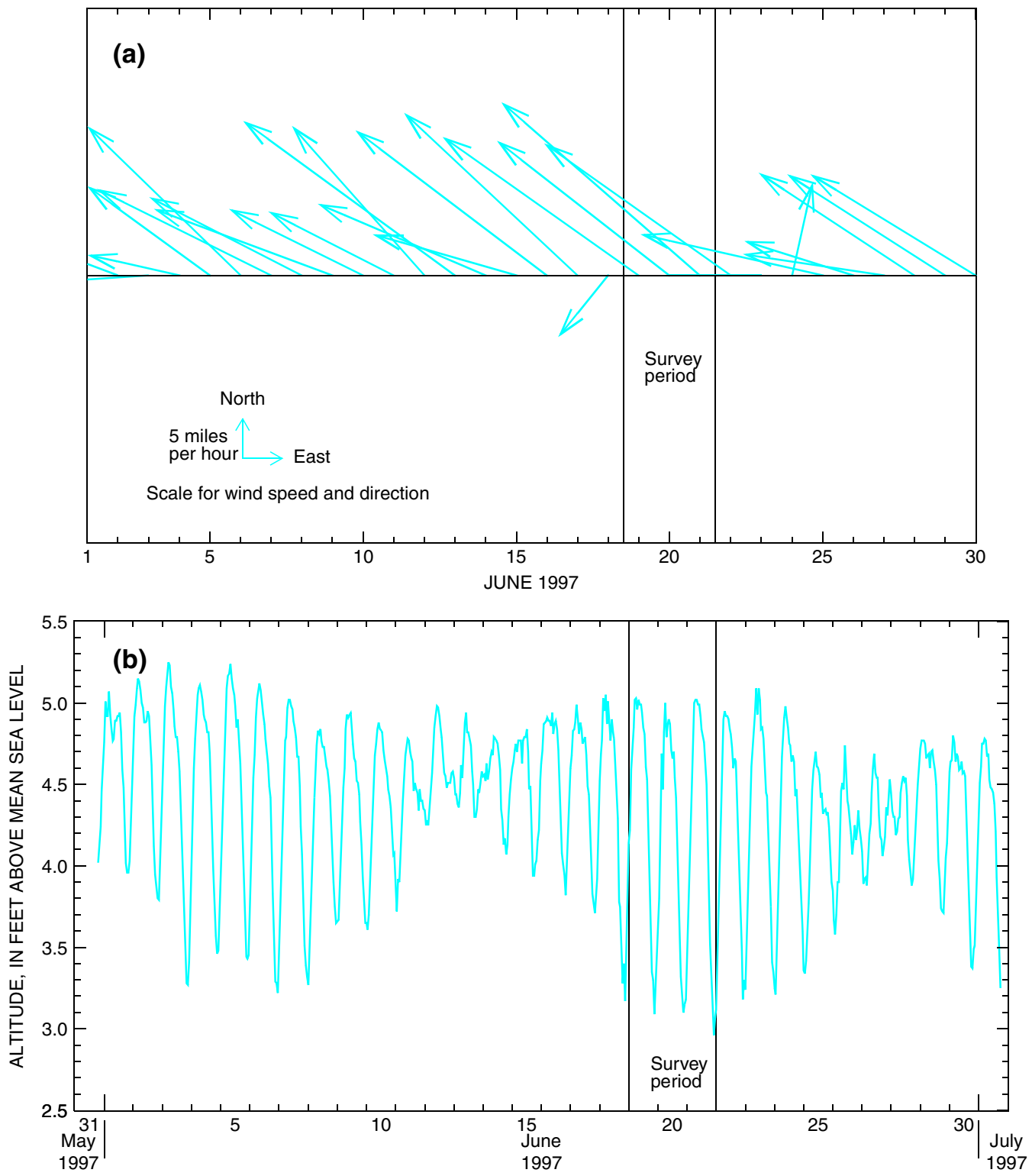

Figure 3. (a) Wind speeds and directions and (b) tidal fluctuations from Texas Coastal Ocean Observation Network station 051 in lower Laguna Madre near Port Isabel, Texas, June 1997.

(site 1) and South Bay Pass (site 2)—and velocity and discharge data at three sites-Brownsville Ship Channel (site 3), Port Isabel Channel (site 4), and Laguna Madre at Queen Isabella Causeway (site 5) (fig. 2).

\section{Meteorological Conditions}

During June 1997, about 1 inch of rain was recorded by the gage at Harlingen International Airport; only 0.05 inch of rain was recorded during the June 19-22 survey, which is consistent with the observation of trace amounts of rainfall during the approximately 74-hour survey. Therefore, appreciable inflows of storm runoff to the southern end of lower Laguna Madre during the survey were unlikely.

Wind vectors-arrows in which the length is proportional to the wind speed and the orientation indicates the direction that the wind was blowing - show that during the survey the wind typically originated from the southeast and blew to the northwest and that maximum wind velocity was about 30 miles per hour (fig. 3a). Wind vectors from TCOON station 051 for earlier time periods indicate that the June 19-22 data are typical of wind patterns in lower Laguna Madre near Port Isabel.

The survey period was chosen to coincide with the period of annual maximum tidal fluctuation so that annual maximum tidal inflows to and outflows from the southern end of lower Laguna Madre could be measured. The daily tidal fluctuations recorded at the TCOON station during June 1997 ranged from less than 1 foot to about 2 feet (fig. 3b).

\section{Velocity and Stage Measurements}

Instantaneous measurements of flow velocity were recorded by electronic data loggers at the five USGS and TWDB sites. Two types of velocity meters were used at the sites-acoustic 
Table 1. Types of velocity meters and velocity recording intervals at lower Laguna Madre discharge measurement sites

[APVM, acoustic point-velocity meter; AVM, acoustic velocity meter]

\begin{tabular}{clcc}
\hline $\begin{array}{c}\text { Site } \\
\text { number }\end{array}$ & \multicolumn{1}{c}{ Site name } & $\begin{array}{c}\text { Type of velocity } \\
\text { meter }\end{array}$ & $\begin{array}{c}\text { Recording interval } \\
\text { (minutes) }\end{array}$ \\
\hline 1 & Laguna Madre at Brazos Santiago Pass & APVM & 15 \\
2 & South Bay Pass & APVM & 6 \\
3 & Brownsville Ship Channel & APVM & 15 \\
4 & Port Isabel Channel & AVM & 15 \\
5 & Laguna Madre at Queen Isabella Causeway & APVM & 15 \\
\hline
\end{tabular}

point-velocity meters (APVM) and acoustic velocity meters (AVM) - to record velocity at intervals of 15 minutes or less (table 1). An APVM measures water velocity at a single point using a Doppler phase-shift technique (Dunn and others, 1997). An AVM measures the velocity along an acoustic path set diagonal to flow (Laenen, 1985). Project personnel attempted to place the meters at locations in a channel where the meters would record velocities that were representative of overall flow conditions in the entire channel.

Stage was measured by sensors connected to submersible pressure transducers.

\section{Discharge Measurements}

A boat-mounted broadband acoustic Doppler current profiler (ADCP) was used to measure the tidally affected discharge at each of the sites. The ADCP uses acoustic signals to measure water velocity, water depth, and boat location at multiple depths and locations as the ADCP traverses a channel. These data are composited and used to compute a discharge for a given transect. Discharge measurements were made hourly, coincident with velocity measurements that were recorded at the five sites.

\section{Discharge Ratings and Computation}

Velocity and stage measurements in tidally affected channels can be related to corresponding discharges measured with an ADCP using regression methods as described by Dunn and others (1997). At three of the five sites (sites 1, 4, and 5), velocity measurements were related to ADCP discharge measurements through regression analysis. At South Bay Pass (site 2), velocity and stage measurements were related to ADCP discharge measurements. Discharges at Brownsville Ship Channel (site 3) were computed on the basis of discharges at sites 1,2, and 5 .

Regression equations of the following form were used:

$$
\mathrm{Q}=\mathrm{B}_{1}+\mathrm{B}_{2} \mathrm{~V}+\mathrm{B}_{3} \mathrm{~S}
$$

where $\mathrm{Q}$ is the estimated discharge in cubic feet per second, $\mathrm{B}_{1}$, $\mathrm{B}_{2}$, and $\mathrm{B}_{3}$ are the regression coefficients, $\mathrm{V}$ is the measured velocity in feet per second, and $\mathrm{S}$ is the measured stage in feet above (+) or below (-) the mean stage measured during the hydrographic survey. The regression equations allow the computation of discharge from a single velocity (and possibly stage) measurement. The regression equation coefficients and coefficients of determination are listed in table 2.

Table 2. Regression coefficients and coefficients of determination for discharge ratings at lower Laguna Madre discharge measurement sites

[equation: $\mathrm{Q}=\mathrm{B}_{1}+\mathrm{B}_{2} \mathrm{~V}+\mathrm{B}_{3} \mathrm{~S}$, where $\mathrm{Q}$ is estimated discharge in cubic feet per second, $\mathrm{B}_{1}, \mathrm{~B}_{2}$, and $\mathrm{B}_{3}$ are regression coefficients, $\mathrm{V}$ is measured velocity in feet per second, and $\mathrm{S}$ is measured stage in feet above (+) or below (-) the mean stage measured during the hydrographic survey. $\mathrm{R}^{2}$, coefficient of determination (variability in the measured discharges explained by the equation); $\mathrm{n} / \mathrm{a}$, not applicable]

\begin{tabular}{clcrrr}
\hline $\begin{array}{c}\text { Site } \\
\text { number }\end{array}$ & \multicolumn{1}{c}{ Site name } & $\mathbf{B}_{\mathbf{1}}$ & $\mathbf{B}_{\mathbf{2}}$ & $\mathbf{B}_{\mathbf{3}}$ & $\mathbf{R}^{\mathbf{2}}$ \\
\hline 1 & Laguna Madre at Brazos Santiago Pass & -348 & 50,739 & 0 & 0.96 \\
2 & South Bay Pass & 147 & 5,474 & -325 & .97 \\
3 & Brownsville Ship Channel & $\mathrm{n} / \mathrm{a}$ & $\mathrm{n} / \mathrm{a}$ & $\mathrm{n} / \mathrm{a}$ & $\mathrm{n} / \mathrm{a}$ \\
4 & Port Isabel Channel & $-4,446$ & 16,903 & 0 & .81 \\
5 & Laguna Madre at Queen Isabella Causeway & $-1,560$ & 36,356 & 0 & .98 \\
\hline
\end{tabular}




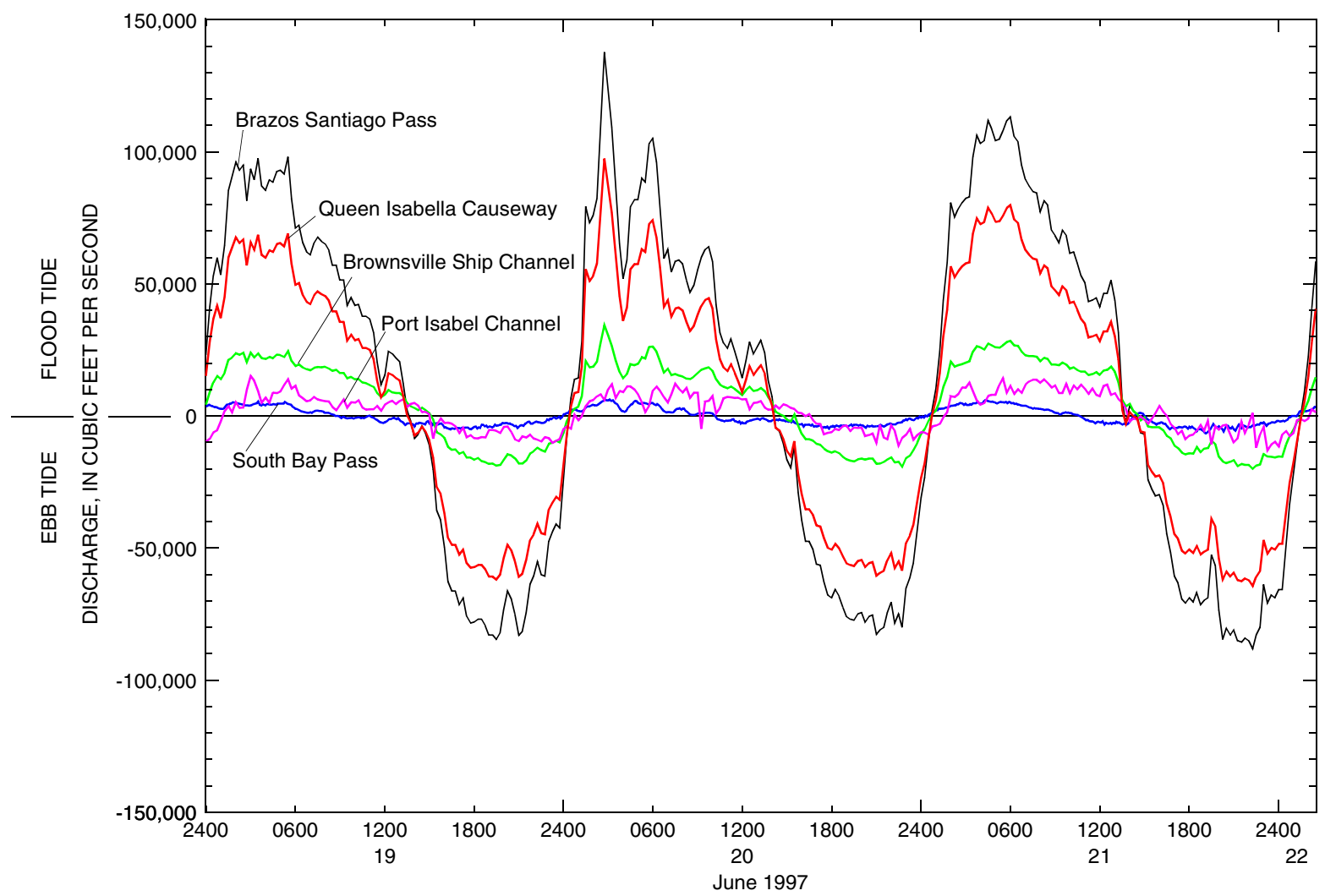

Figure 4. Estimated discharges at five sites in lower Laguna Madre near Port Isabel, Texas, June 19-22, 1997.

Review of velocity data collected at Brazos Santiago Pass (site 1) indicated that the data were not representative of the entire channel, probably because of the near-shore location of the velocity meter. U.S. Coast Guard regulations prevented location of the velocity-measuring equipment in the open channel of Brazos Santiago Pass. Because of this, useful regression equations could not be developed from velocity data and velocity/stage data collected at the site. Therefore, discharge measurements made at Brazos Santiago Pass were regressed with concurrent velocity data that were collected at Queen Isabella Causeway (site 5).

Efforts to develop regression equations for Brownsville Ship Channel (site 3) also were unsuccessful. Estimated discharges at three of the other sites were used to compute discharge at this site. The authors assumed that flow into and out of storage in the estuary was negligible during the 74-hour survey period. Under this assumption, all flow through Brazos Santiago Pass (site 1) would have to pass one of three other sites, South Bay Pass (site 2), Brownsville Ship Channel (site 3), and Queen Isabella Causeway (site 5). Therefore, the sum of discharges at South Bay Pass, Brownsville Ship Channel, and Queen Isabella Causeway were set equal to the discharge at Brazos Santiago Pass. Flow at the Brownsville Ship Channel site was then computed as the discharge at Brazos Santiago Pass minus the sum of discharges at South Bay Pass and Queen Isabella Causeway ${ }^{1}$.

\section{Discharges}

Hydrographs of discharges estimated from the ratings at sites 1, 2,4 , and 5 and computed as described for site 3 were superimposed for comparison of flows at the sites during the survey (fig. 4). Flood tide flows were considered positive discharges, and ebb tide flows were considered negative discharges. Figure 4 shows that inflow (flood tide flow) and outflow (ebb tide flow) through Brazos Santiago Pass coincided with flow past Queen Isabella Causeway, which was in a northerly direction during flood tide and a southerly direction during ebb tide. Tidal flows of lesser magnitude cycled into and out of Brownsville Ship Channel and Port Isabel Channel. Relatively small rates of inflow and outflow occurred in South Bay Pass. Inflow to lower Laguna Madre from South Bay occurred during ebb tide and outflow from Laguna occurred during flood tide.

The discharge data were used to compute the cumulative net discharge volume for the three diurnal tidal cycles of the survey period for each site (fig. 2; table 3). During the approximately 74-hour period, there was a net inflow to lower Laguna Madre through Brazos Santiago Pass of 59,300 acre-feet. This net inflow (plus the relatively small net inflow through South Bay Pass of

1 To check the reasonableness of this computation, the estimated discharges at the Brownsville Ship Channel site were compared with discharges measured at the same site by an ADCP during June 6-7, 1997. The estimated discharges for the survey period ranged from $-17,500$ to 34,700 cubic feet per second. (Flood tide flows were considered positive discharges, and ebb tide flows were considered negative discharges.) The June 6-7 ADCP discharges ranged from -17,400 to 22,200 cubic feet per second. This comparison shows that the estimated discharges are of the same order of magnitude as the discharges measured on June 6-7. Also, because the 74-hour survey period coincided with the period of annual maximum tidal fluctuation, discharges would be expected to have been greater during the survey than during June 6-7. Therefore, the authors believe the estimated discharges for Brownsville Ship Channel are reasonable, although the assumption of negligible storage was not verified. 
Table 3. Maximum discharges and velocities during flood and ebb tides and net discharge volumes at lower Laguna Madre discharge measurement sites, June 19-21, 1997

[n/a, not available]

\begin{tabular}{|c|c|c|c|c|c|c|}
\hline \multirow[b]{2}{*}{$\begin{array}{c}\text { Site } \\
\text { number }\end{array}$} & \multirow[b]{2}{*}{ Site name } & \multicolumn{2}{|c|}{ Flood tide } & \multicolumn{2}{|c|}{ Ebb tide } & \multirow[b]{2}{*}{$\begin{array}{c}\text { Net } \\
\text { discharge } \\
\text { volume } \\
\text { (acre-feet) }\end{array}$} \\
\hline & & $\begin{array}{l}\text { Maximum } \\
\text { discharge } \\
\text { (cubic feet } \\
\text { per second) }\end{array}$ & $\begin{array}{c}\text { Maximum } \\
\text { velocity } \\
\text { (feet per } \\
\text { second) }\end{array}$ & $\begin{array}{l}\text { Maximum } \\
\text { discharge } \\
\text { (cubic feet } \\
\text { per second) }\end{array}$ & $\begin{array}{c}\text { Maximum } \\
\text { velocity } \\
\text { (feet per } \\
\text { second) }\end{array}$ & \\
\hline 1 & Laguna Madre at Brazos Santiago Pass & 138,000 & $1_{2.72}$ & $-88,100$ & ${ }^{1}-1.73$ & 59,300 \\
\hline 2 & South Bay Pass & 5,970 & 1.24 & $-6,070$ & -1.17 & 2,190 \\
\hline 3 & Brownsville Ship Channel & ${ }^{2} 34,700$ & $\mathrm{n} / \mathrm{a}$ & $2-17,500$ & $\mathrm{n} / \mathrm{a}$ & 27,000 \\
\hline 4 & Port Isabel Channel & 15,000 & 1.15 & $-13,100$ & -.51 & 8,880 \\
\hline 5 & Laguna Madre at Queen Isabella Causeway & 97,300 & 2.72 & $-64,500$ & -1.73 & 34,500 \\
\hline
\end{tabular}

${ }^{1}$ Velocity data from site 5.

${ }^{2}$ Computed as the discharge at site 1 minus the sum of discharges at sites 2 and 5.

2,190 acre-feet) resulted in a net flow north in lower Laguna Madre of 43,400 acre-feet, which is obtained by summing the net flow at Queen Isabella Causeway (34,500 acre-feet) and the net flow in Port Isabel Channel (8,880 acre-feet). About 71 percent of the net inflow to the estuary through Brazos Santiago Pass and South Bay Pass flowed north in lower Laguna Madre, which supports the hypothesis of Hedgpeth (1967, p. 410) that water generally enters lower Laguna Madre through Brazos Santiago Pass and flows northward toward Port Mansfield Channel. There was a net flow up Brownsville Ship Channel of 18,100 acre-feet, which is obtained by subtracting the net flow in Port Isabel Channel $(8,880$ acre-feet) from the net inflow to Brownsville Ship Channel estimated at the entrance to the channel (site 3) (27,000 acre-feet).

The net inflow to lower Laguna Madre from South Bay during the survey probably is the result of wind-driven flow. South Bay is a shallow estuary, and the prevailing winds during the survey were from the southeast to the northwest (fig. 3).

\section{References}

Dunn, D.D., Solis, R.S., and Ockerman, D.J., 1997, Discharge measurements in tidally affected channels during a hydrographic estuarine survey of Sabine Lake, Texas: U.S. Geological Survey Fact Sheet FS-157-97, 6 p.

Hedgpeth, J.W., 1967, Ecological aspects of the Laguna Madre, a hypersaline estuary, in Lauff, G.H., ed., Estuaries:
Washington, D.C., American Association for the Advancement of Science Publication 83, p. 408-419.

Laenen, Antonius, 1985, Acoustic velocity meter systems: U.S. Geological Survey Techniques of Water-Resources Investigations, book 3, chap. A17, 38 p.

Texas Department of Water Resources, 1983, Laguna Madre Estuary-A study of the influence of freshwater inflows: Texas Department of Water Resources LP-182 [variously paged].

— J.W. East ${ }^{2}$, R.S. Solis ${ }^{3}$, and D.J. Ockerman ${ }^{2}$

Any use of trade, product, or firm names is for descriptive purposes only and does not imply endorsement by the U.S. Government.

Information on technical reports and hydrologic data related to this study can be obtained from

Subdistrict Chief

U.S. Geological Survey

2320 La Branch Street

Houston, TX 77004

Phone: (713) 718-3655

FAX: (713) 718-3661

World Wide Web: http://tx.usgs.gov

${ }^{2}$ U.S. Geological Survey.

3 Texas Water Development Board. 